\title{
An online instrument assessing the relationship between morphological structure awareness and reading comprehension in Hungarian 2-4 graders
}

\author{
Szilvia Varga, John von Neumann University, Hungary, t.vargaszilvia@gmail.com \\ ORCID: 0000-0002-0229-4343 \\ Attila Pásztor, MTA-SZTE Research Group on the Development of Competencies, Hungary, \\ attila.pasztor@gmail.com ORCID: 0000-0001-8441-446X \\ János Steklács, PTE Institute of Hungarian Language and Literature, Department of Linguistics, Hungary, \\ steklacs@gmail.com ORCID: 0000-0003-0998-6278
}

\begin{abstract}
The significant contribution of morphological awareness to reading comprehension has been shown in studies with deep orthographies. The aim of the study was to develop an online instrument in Hungarian, an agglutinative language with a transparent orthography and a rich morphology, for assessing different aspects of morphological awareness and reading comprehension and to examine the development and relationship of the two constructs in grades 2-4. Participants were second $(\mathrm{N}=124)$, third $(\mathrm{N}=137)$, and fourth-grade students $(\mathrm{N}=97)$, age means were 8.7, 9.6 and 10.4 respectively. We found growth in the development of morphological awareness and reading comprehension in grades 2-4; however, the mean score in grade 4 did not significantly differ from the results in grade 3 . Significant moderate correlations were found between morphological structure awareness and reading comprehension skills in all grades.
\end{abstract}

Keywords: Morphological structure awareness, reading comprehension, online instrument

\section{INTRODUCTION}

\section{Acquisition of Reading Skills and Morphological Awareness}

Good reading skills are essential for success both at school and in society (Csapó \& Csépe, 2012; Grabe \& Stoller, 2011). Reading skills have a strong link to language acquisition and thinking skills (Bloomert \& Csépe, 2012; Vygotsky, 1962; Ziegler \& Goswami, 2005). According to the current theories, reading comprehension has two main pillars: Decoding and language comprehension (Gough \& Tunmer, 1986). Decoding involves processing orthographic, linguistic and semantic information; the acquisition of different skills like phonological awareness, morphological awareness, and vocabulary; a mass of empirical evidence justifies the contribution of these skills to the reading process (Apel et al., 2013; Carlisle, 1995; Carlisle, 2000; Verhoeven \& Perfetti, 2017). "However, reading is more than converting orthographic forms into phonological forms. Comprehension can only be achieved when the converted phonological information is mapped onto semantic information" (Kuo \& Anderson, 2006, p.162). The smallest phonological units that convey semantic information are morphemes. The metalinguistic skill to identify, reflect on, manipulate morphemes and apply the word formation rules is referred to as morphological awareness (Apel et al., 2013; Kuo \& Anderson, 2006; Levesque et al., 2017). Morphological knowledge can support the identification of morphologically complex words through nonlexical word processing (Rastle, 2019). For example, in Hungarian the word gyorsan (quickly) consists of two morphemes. In order to identify the meaning of the word gyorsan (quickly), you need to understand the meaning of the morphemes: The stem gyors (quick), which denotes a quality of moving at a high speed and the suffix - an (ly), which means in a stated way.

Reading models in the last few decades have ignored the role of morphology. Morphology only appears as part of the linguistic or semantic system which influences word reading and 
processing of semantic information. The contribution of morphological processing to reading comprehension started to gain importance when reading and brain research found that word recognition is an important factor in explaining reading difficulties (Verhoeven \& Perfetti, 2011). Morphological awareness is increasingly important especially when a morphologically complex word is recognized automatically (Carlisle, 2000; Nagy, Carlisle \& Goodwin 2014). Since the early 1980s, computational models have been created in order to explain cognitive processes underlying reading, for instance, models of word identification, reading aloud and processing morphologically complex words.

According to Coltheart's (2005) hypothesis on dual-route of word recognition it is suggested that there are two routes of word recognition. The first one is the lexical route which means recognizing words by sight. This route is activated when frequent monomorphemic words are recognized. The second one is considered to be the non-lexical route which is employed when encountering an unfamiliar word and in order to understand its meaning through the analysis of the constituent morphemes. In the case of a morphologically complex word Verhoeven and Perfetti (2011) emphasize the importance of the non-lexical route. They argued that splitting the words into morphemes can happen at the initial phase of word identification directly from the orthographic form or indirectly when the orthographic units are processed. Word meanings can be identified automatically by using the patterns of phonemegrapheme correspondence rules; if there is a pattern for them (lexical-route), or if the word form is morphologically complex, the brain tries to decompose it by separating the component morphemes.

Children's morphological knowledge increases through the primary school years as a result of experiences with print. Therefore, the relationship between morphological awareness and reading comprehension is possibly bidirectional, implying that two skills can support each other (Carlisle, 2000).

The orthography of the language determines how easy or difficult it is to predict the pronunciation of a word based on its spelling. Therefore, the orthography of the language has an impact on how words are recognized in reading development as well. The orthographic depth hypothesis emphasizes the importance of connections between orthographies of languages and the reading process. According to Katz and Frost (1992), orthographic depth indicates the degree to which a written language deviates from grapheme-phoneme correspondence. In deep orthographies the grapheme-phoneme correspondence is not consistent. In languages with relatively deep orthographies, new readers have difficulty learning to decode words; as a result, children learn to read more slowly (Aro, 2017; Grabe \& Stoller, 2011). Deep orthographies require a reader to process printed words through the application of morphology skills. However, in shallow orthographies, the spelling-sound correspondence is direct; one can pronounce the word correctly from the rules of pronunciation. Consequently, words can be identified more easily. In shallow orthographies, like Hungarian children learn how to decode the written symbols more easily and quickly. Nevertheless, decoding is not equivalent to comprehension and there is a lack of empirical data about how morphological knowledge influences word recognition and the role it plays in reading comprehension in an agglutinative language with a shallow orthography and a rich morphology. This study aims to develop an online instrument in Hungarian for assessing different aspects of morphological awareness and reading comprehension and to examine the development and the relationship of the two constructs in grades 2-4 (from ages 8 to 10).

\section{Definition of Morphological Awareness}

Morphological awareness is defined as "children's conscious awareness of the morphemic structure of words and their ability to reflect on and manipulate that structure" (Carlisle, 1995, p. 194). Kuo and Anderson (2006) think that it is "the ability to reflect upon and manipulate morphemes and employ word formation rules in one's language..."(p. 161). According to Deacon et al. (2014) morphological awareness is "the awareness of and ability to manipulate the smallest meaningful units or morphemes" (p. 432). There is a debate among researchers about the concept of awareness. Pléh (2000) defines the term awareness as implicit rather than 
explicit knowledge which means that when children acquire different morphological elements, they usually cannot give clear concepts about why they use one or another inflectional affix and different inflected forms. Other researchers e.g. Nagy et al.(2014) make a distinction between awareness, conscious knowledge, and tacit knowledge. Tacit knowledge is related to the unconscious knowledge that the speaker of a language is familiar with the rules determining the grammatical correctness of the sentences of the given language. Linguistic competence is a system of rules, or grammar that represents the speaker's knowledge of his language (Nagy, et al., 2014). This knowledge is considered to be unconscious since speakers are unaware of the rules when they use the language. The speakers are unable to recall the rules which they utilized during speech production and comprehension when reflecting on what they said or heard. When a native speaker can judge whether a particular phrase or sentence is right or wrong, it is called linguistic intuition (Nagy et al., 2014).

Carlisle (2000) identified two dimensions of morphological awareness: Morphological structure awareness and morphological analysis. Morphological structure awareness is children's awareness of the grammatical structures of the language without arriving at word meaning. The morphological analysis includes the use of morphological structures to determine the meaning of words (Carlisle, 2000; Deacon, et al., 2017). Kuo and Anderson (2006) added a third dimension: Morphological decoding, which is the ability to use morphemes to arrive at an accurate pronunciation of a written word.

\section{Measures to Assess Morphological Awareness}

Morphological awareness includes awareness of the spoken and written forms of morphemes, either the base words or affixes that are attached to the base word. Morphological awareness has been measured in several ways. Apel et al. (2013) distinguish different ways to assess morphological awareness, for example, judgment, production and identification, partly oral, and written tasks. Children are either tested individually, orally and face to face (Levesque et al., 2017) or in a group, using paper-based tests or the combination of different methods (Apel et al., 2013). Computerized tests are also used as part of the research, for example, in word recognition tasks (Acha, et al., 2010); however, there is no online instrument available assessing more aspects of morphological awareness.

Different tests aim to measure three dimensions of morphological awareness: Morphological structure awareness, morphological analysis (Carlisle, 2000) and, morphological decoding (Deacon et al., 2017; Kuo \& Anderson, 2006). Measures for assessing morphological awareness have been discussed in several studies (Apel et al., 2013; Carlisle, 1995, 2000; Deacon et al., 2017; Kuo \& Anderson, 2006). Common methods for measuring morphological structure awareness were identified by Carisle (2000). The production tasks on the assessment ask students to produce an inflected or derived word form. Students must complete a sentence with a given word, for example, "farm. My uncle is a __" (Carlisle, 2000, p.187). In the analogy tasks children use the same morphological manipulation on a different word pair or sentence pair; for example " walk: walked: run:_" (Nunes et al., 1997, p. 649). The emphasis in these exercises is on the child's ability to manipulate the morphological structure of the word to fit the context. The tasks test the child's awareness of the structure of the words (Kirby et al., 2012). Morphological decoding is the ability to use morphemes to arrive at an accurate pronunciation of a written word (Kuo \& Anderson, 2006). Word reading exercises can particularly work for orthographically opaque languages where children have challenges decoding the graphical symbols because the letter-sound correspondence follows difficult patterns. Morphological analysis can be associated with morphological problem-solving. It tests the use of morphological structure to determine the meaning of words (Carlisle, 2000). Typical exercises include defining derived words and base words. The "relatives" tasks are similar to the ones created by Carlisle (2000), that is, children have to produce inflected forms of the given word.

For morphological testing, nonwords are also used with real affixes to assess children's awareness of the grammatical structures (Apel et al., 2013; Berko, 1958). In his well-known Wug test, Berko (1958) used pseudowords to test children's morphological skills that proved to be the most effective method to assess children's metalinguistic skills. 


\section{Development of Morphological Awareness}

The development of morphological knowledge starts with language acquisition. Based on brain research, it can be hypothesized that acquisition of inflectional morphology takes place relatively early; thus, by age 4 children use inflectional morphology with a certain amount of flexibility (Gábor \& Lukács, 2012; Rastle, 2019). Children acquire morphological structures easily since morphology marks the grammatical relationships locally, which makes it easier to recognize the typical patterns and use them to create new forms using analogies. This feature makes it possible for children to get access to basic morphological structures relatively early during language acquisition. Hungarian children acquire morphological rules before four years of age, the use of affixes precedes the acquisition of syntax. Research findings show that morphological productivity appears as well. Children can use nouns and verbs with considerable ease, even with nonwords. In the case of new verbs, children coped with more difficulty, but mostly gave correct answers (Gábor \& Lukács, 2012).

Berko (1958) was the first researcher to systematically test children's morphological knowledge with his Wug test. He investigated the acquisition of morphological knowledge in three different dimensions: Inflectional, derivational and compound morphology. Based on his study, many researchers investigated the acquisition of this skill using this pattern (Apel et al., 2013; Carlisle, 2000; Deacon et al., 2014; Kuo \& Anderson, 2006; Levesque et al., 2017). Both inflections and derivation involve attaching affixes to the words. Inflections change the word form while maintaining the same word; however, a derivational rule may change the syntactic category or the lexical meaning of the stem to which it is attached. Compound words are combinations of two or more words; they often have a meaning that is different, or more specific, than the two individual words. Acquisition of inflectional morphology encompasses the syntactic relations between the monosyntactic content of the words that is the difference in tense, number/person, and agreement, and their morphological forms. Inflectional suffixes are bound morphemes that convey grammatical information. English has relatively few inflectional morphemes; however, Hungarian has plenty of inflections. The number on a noun belongs to inflectional morphology. For example, for English nouns the inflectional morpheme for the plural is an -s, or -es. - "girls, houses". In Hungarian, the morpheme for the plurals is a $-k,-a k$, $e k$, -ok - székek - "chairs" as well as -i,-ai, -ei,-jai, -jei - gyermekei - "children". Children acquire the use of inflectional morphology before learning to use the syntax (Gábor \& Lukács, 2012; MacWhinney, 1976).

Berko (1958) conducted systematic research on children's inflectional morphology skills. He tested children between the ages of 4 and 7. The assessment tasks tested sentences with a pseudoword in it; children had to form the plural, verb tense, or possessive form of the pseudoword. The "Wug" test usage nonwords proved to be the most effective measure to analyze a child's awareness of morphological structures as the child could not rely on word meaning of the words, therefore; metalinguistic awareness skills were used (Kuo \& Anderson, 2006). The Wug test demonstrates that preschool children already have some knowledge of the inflectional markers and a basic ability to manipulate new words. Berko's findings also suggest that such knowledge improves significantly from preschool to the first grade. In addition, children acquire most inflectional rules by early elementary grades (Berko, 1958; Kuo \& Anderson, 2006). Other research findings also support that children use inflections in natural speech (Gábor \& Lukács, 2012). Gábor and Lukács (2012) examined the morphological productivity of morpheme use in Hungarian children aged between ages 3 and 5 . They tested how children could produce inflected forms through nonwords, for example, children were taught the pseudoword gaku, and then, asked questions. In their answers children had to use different inflections formed from nonwords. Children were taught a pseudo-verb and a pseudosuffix as well. The findings suggest that children can use nominal and verbal suffixes productively, although noun morphology seemed to be more difficult than verb morphology. Also, children in the oldest group were able to understand the new suffix; however, they struggled to produce new words using the pseudo-suffix. This might apply that children's 
morphological awareness was not developed enough to enable them to use it efficiently (Gábor \& Lukács, 2012).

Although children can utilize inflectional suffixes by the early elementary grades, they still have trouble understanding and producing allomorphs. Allomorphs are actual representations of morphemes, such as the plural endings -s (as in cars). Both good and bad readers possibly develop various depths of understanding an abstract level of morphological presentations; however, most make mistakes in forming some inflected forms (Berko, 1958).

While the acquisition of inflectional morphology is quite developed by the age of four, it takes longer for children to acquire derivational morphology. First graders have a basic knowledge of derived forms (Kuo \& Anderson, 2006). During the third, and the fourth-grade children start to develop explicit awareness of the structure and meaning of derived forms of words (Carlisle, 2000). It is believed that this develops further even throughout the high school years (Berko, 1958). This is the period when metalinguistic knowledge or awareness develops which makes it possible for the child to objectify the language.

Metacognitive awareness begins with a phase where the knowledge is below a threshold level of consciousness. During this phase, children demonstrate a functional control in rich pragmatic contents. This phase develops into the phase of "actual consciousness", then it develops into the "conscious awareness" stage. At this stage, children are able to intentionally concentrate on and manipulate linguistic units (Kuo \& Anderson, 2006).

Inflectional and derivational suffixes differ in the number of suffix types and the frequency of the derived forms. In English, the number of derivational suffixes is limited. However, as the Hungarian language is an agglutinative language, with a rich morphological system, it has a myriad of derivational suffixes. Some common derivational suffixes form a verb from another verb (öltöz -"dress" plus the verb -ködik, becomes öltözködik "get dressed"), $a$ noun from a verb (gyüjt-"collect" plus the suffix -emény, becomes gyütemény "collection" ), a noun from an adjective (szép - "beautiful" plus the suffix - ség, becomes szépség - "beauty"), a verb from an adjective (szép - "beautiful" plus the suffix -ít, becomes szépít - "beautify", a participle from a verb (ír/írás - "write/writing").

There has been little research on the acquisition of compounds. Berko (1958) examined to what extent children acquired awareness of compound morphology. He asked children to explain the meanings of compound words. Preschoolers had developed very limited awareness related to the structure of compound words. Instead of decomposing compound words, preschool children tend to store them as a single lexical item regardless of their structure. Pléh (2000) investigated into the overgeneralizations regarding compound words. He found that preschool children acquire morphophonological exceptions later than regular forms, which gives explanations for the mistakes they make in connection with inflectional, derivational, and compound morphology (Pléh, 2000).

\section{Objectives}

The objective of this study was threefold. First, we developed and empirically tested our instrument for measuring morphological awareness. Secondly, we wanted to observe how the skills of morphological awareness and reading comprehension developed together between the second and the fourth grades of primary school. Thirdly, we analyzed the relationship between morphological awareness and reading comprehension.

We developed the following guiding research questions.

1. Can morphological structure awareness be measured by our four-dimensional instrument?

2. How do morphological awareness and reading comprehension skills develop in classes 2-4 of primary school?

3. How do morphological awareness and reading comprehension relate to each other in classes 2-4 of primary school? 


\section{METHODS}

\section{Participants}

The participants were second graders $(\mathrm{n}=124$ age: $\mathrm{M}=8.7, \mathrm{SD}=0.40$ years), third graders $(\mathrm{n}=137$ age: $\mathrm{M}=9.6, \mathrm{SD}=0.45$ years) and fourth graders ( $\mathrm{n}=97$ age: $\mathrm{M}=10.4, \mathrm{SD}=0.63$ years); altogether 356 children were tested (age: $\mathrm{M}=9.5, \mathrm{SD}=0.81$ years). Three children started but did not finish the test. 171 girls and 169 boys completed the test, 16 children did not answer the gender question.

\section{Instruments}

We chose online testing instead of paper-based methods because it was more cost-efficient than face-to-face methods. In addition, it gave immediate feedback, which made the testing procedure more acceptable for both children and teachers. The online test consisted of five sections: Affix identification/real words (10 items), compound words (10 items), derivation (10 items), affix identification/nonwords (10 items), reading comprehension (10 items). The intention of the first four sections of our instrument was to test children's awareness of the basic grammatical structures and the ability to manipulate them. The fifth section assessed reading comprehension.

In the first section, the participants were given affix identification tasks based on analogy and judgment (Apel et al, 2013; Carlisle, 2000). Children had to separate base words from inflected words by placing a word into the correct category boxes of base words and affixed words (Figure 1, left). The instructions were the following: "You can see two boxes on the screen. Drag the base words from the menu into the base word box and inflected words into the affixed word box. We have already put one word into each box as an example. If you click on the question mark, you can learn what base word means and what affixed word means. If students clicked on the word szótö - "base word", the definition for base word was shown, if they clicked on the word toldalék - "affixes", the definition of affix was displayed. Examples and help were provided to ensure that the task measured the skill, and to decrease the effects of a lack of lexical knowledge about the concepts. This task tested how children could recognize base words, when they had the same ending as some inflected words (oceán - "ocean "; táblán- "on the board"; bödön- "pot"; kövön- "on the stone"; banán - "banana"; párnán-"on the pillow" etc.)

The second subtest included compound nouns. Children chose the compound nouns from four words (Figure 1, right), the instruction said: "Choose the compound word which is made up of two words. Answer by clicking on the correct word. " All the four words had the same base word (mos - "wash"; mosás- "washing"; mosógép -"washing machine"; mosni- "to wash", villamos - "tram"). Six items out of ten contained pseudo-compounds like villamos-"tram". These words contained two simple words inside them but still, they were not compound words because their meaning separately had nothing to do with the meaning of the word. (villa - "villa" or "fork"; mos - "wash"; villamos - "tram").

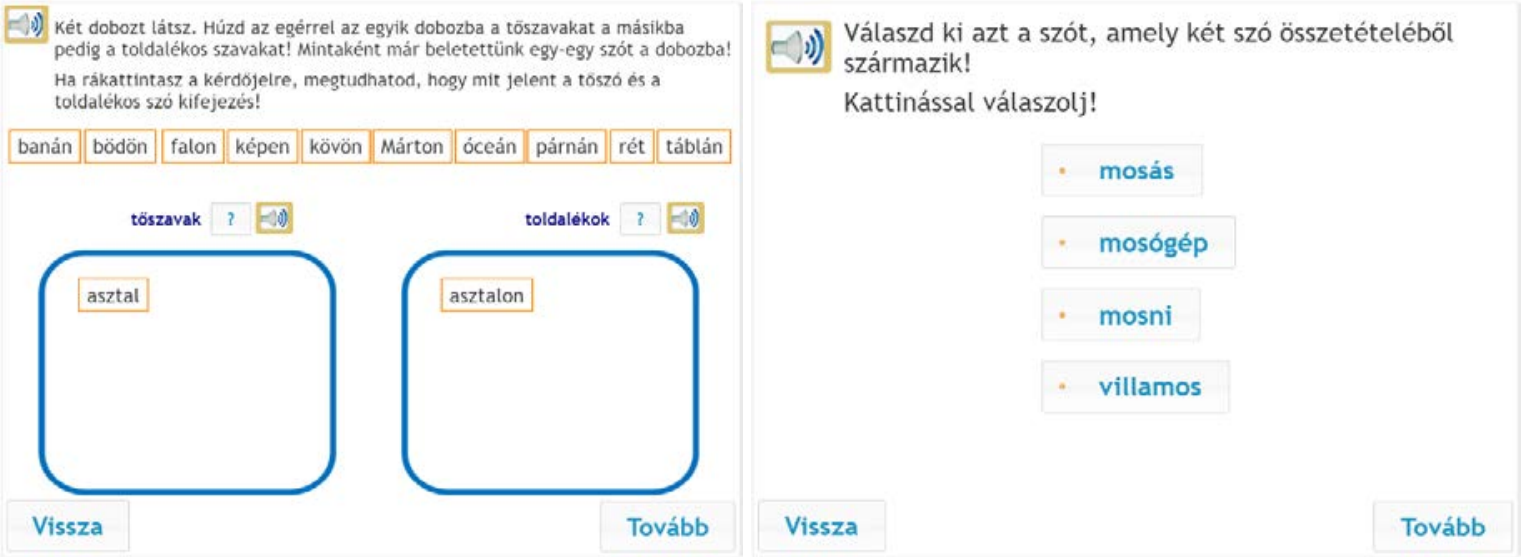

FIGURE 1. Sample items for affix identification (real words) and compounds 
The third subtest was a derivation task using real words (Figure 2, left). Children were asked to choose one from the four-word choices to complete the sentence (Apel et al. 2013; Carlisle, 2000). All the given words had different correct or incorrect versions of the same base word; however, only one had the right derived form. In the derivation subtest, the children got the following instruction: "Complete the following sentence. Drag the appropriate word onto the dotted line." Panni mindig hazamegy ........... után. /tanítós/tanítás/tanítani/tanítások/. "Panni always goes home after .......... /teacherly/teaching/teach/teachings/".

The fourth subtest contained nonwords testing identification of affixes using nonwords to which real affixes were attached (Apel et al., 2013; Berko, 1958). Identification of affixes of singular and plural nouns, present and past of frequent verbs, and objective and instrumental cases of nouns were assessed. Two types of tasks were given. Either a question had to be answered by clicking on the correct sentence, or the correct sentence had to be selected from the four choices (Figure 2, right). In the nonword task, children got the following information: "These are marinoszes. What do you say if there is only one animal in the picture? Answer by clicking. a) It is a marinosza., b) It is a marinosz., c) It is a marinoszt d)It is a marinoszi."

Egészítsd ki a mondatot!

Húzd a megfelelö szót a pontozott vonalra!

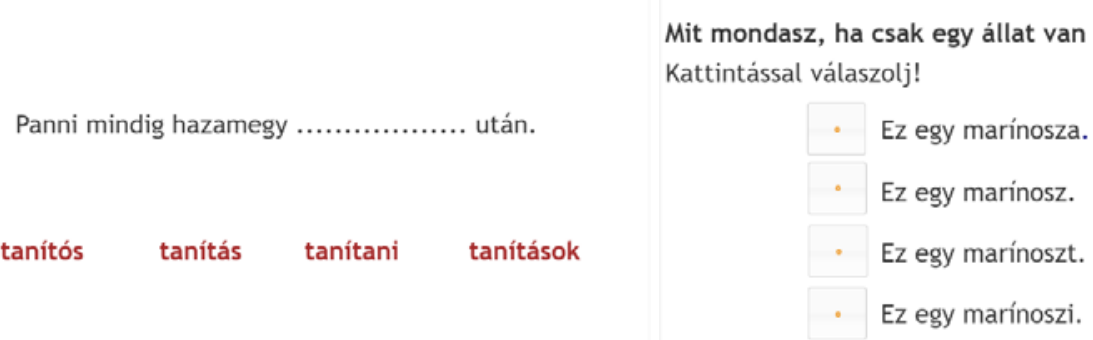

Vissza

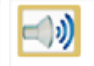

Ezek marínoszok:

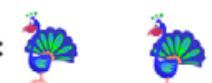

Ez egrinoszi.

\section{FIGURE 2. Sample items for derivation and identification of affixes for nonword exercises}

Our test partly measured morphological knowledge (tacit knowledge), that is, whether children could use word formation rules (derivation, compound words), and partly it tested morphological structure awareness in affix identification of real words and affix identification in nonwords tasks. In the affix identification of real words task children had to select the base from the affixed words when the orthographic forms were very similar and in the affix identification nonwords task, children had to identify the correct inflections without relying on the meaning of words.

The fifth subtest was the reading comprehension test. This section had a short continuous text followed by ten multiple-choice questions (Figure 3). The following instructions were given: "Read the following text and answer the question by clicking on the correct answer." Sample question: "How often is the festival organized? a) every year b) every six months c) every month d) every second-year" Children had to retrieve detailed information from the text. The questions followed the order of the events in the text, which was about an imaginary festival for children. The text contained a great deal of detailed information; therefore, different reading strategies were needed; for instance, scanning through the text to find the right answers. The text was displayed with the questions; therefore; a student could refer to the text if it was needed. The text was adapted from a brochure about a festival; some names and data were modified and the text was made simpler and shorter for children.

\section{Procedures}

Data collection was carried out in Hungary in spring 2019. The tests were delivered through the eDia platform (Csapó \& Molnár, 2019). Children were given an identification code to log-on to the test. Teachers could only assist children with accessing the eDia platform; after entering the 
test, children could work on their own. Scores were anonymous as they were attached to the identification code rather than a student's name. Parental consent was asked from the parents, and only the students whose parents granted consent participated in the experiment.

Olvasd el az alábbi szöveget és kattintással válaszolj a kérdésrel

14. Gyermekvarázs Fesztivál (2018. augusztus 30-szeptember 7.)

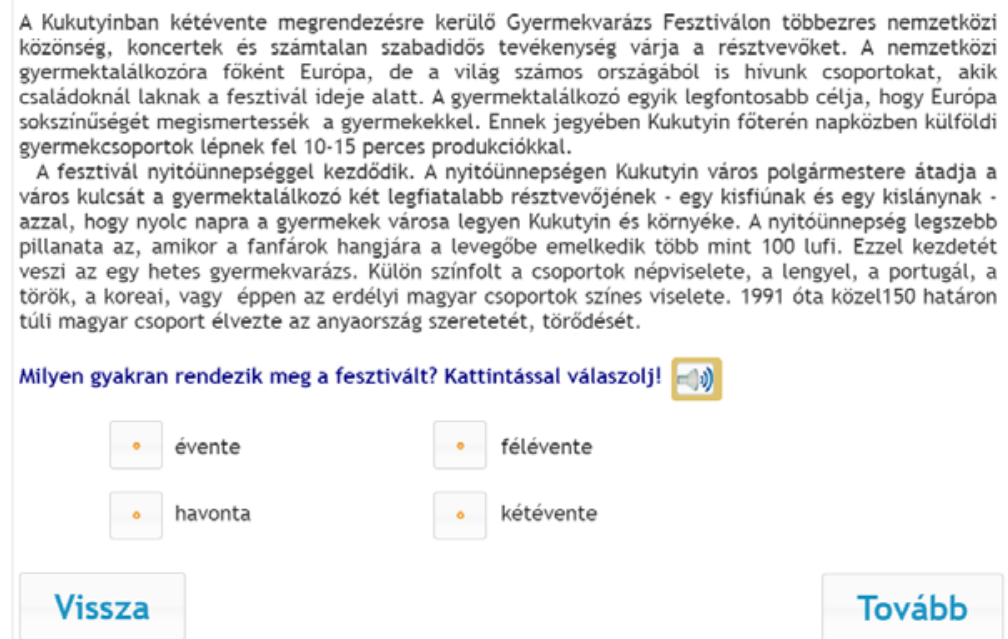

FIGURE 3. The item from the reading comprehension subtest

The online platform had a colorful, child-friendly interface. Children could only listen to the instructions and the questions by using headphones. Before the test, pupils took a demographic questionnaire about their age and gender. Altogether, the test contained two dragand-drop exercises with 20 items about affix identification of real words and derivation. The other 30 items were multiple-choice questions, where children had to click on their answer choice using the radio button. Before all the exercises, an example was provided to familiarize a child with the requirements of the particular task. The test was conducted in a group setting. The entire test took approximately 30 minutes to complete (second grade: $\mathrm{M}=27.3, \mathrm{SD}=9.1$ minutes; third grade: $\mathrm{M}=23.8, \mathrm{SD}=6.3$; fourth grade: $\mathrm{M}=25.4, \mathrm{SD}=11.0$ ).

The scores for each subtest were immediately displayed on the monitor when a child had finished the test. Each student was rewarded for taking part in the survey with a nice colourful image of a piglet with a bunch of balloons. The number of balloons displayed corresponded to the total score; i.e., higher achievements were rewarded with more balloons. The scores of the children also could be downloaded from the eDia platform. Besides the scores, teachers also could download a detailed description of the test and personalized feedback for each child. It contained written feedback for different achievement categories and a spider web diagram, which showed the performance of a given child compared to his/her classmates and the average performance of the given grade. The feedback details provided teachers and school principals information about a child's performances that could help increase the teaching efficiency (Csapó \& Molnár, 2019).

\section{RESULTS}

The overall Morphological Structure Awareness and the Reading Comprehension tests showed good reliability in all grades (see Table 1). The 10 items subtests showed good or still acceptable reliabilities, except the derivation subtest in grade 3 (Table 1). The derivation and Affix Identification/Nonwords subtests had the lowest performances in all grades. All individual item scores were positively correlated with the test scores; therefore, further improvement of the Cronbach's alpha values could not be carried out by removing some items. Despite these lower reliabilities, both subtests measured important aspects of morphological awareness. 
Thus, they were important for the validity of the test; and were kept for further analyses. The highest performances were in grade 4, except the Affix Identification/Nonwords subtest.

Table 1. Reliability of the whole test and its subtest: Cronbach's alpha indices for grades 2-4

\begin{tabular}{lcccc}
\hline & $\begin{array}{c}\text { All grades } \\
(\mathrm{N}=356)\end{array}$ & $\begin{array}{c}\text { Grade 2 } \\
(\mathrm{n}=122)\end{array}$ & $\begin{array}{c}\text { Grade 3 } \\
(\mathrm{n}=136)\end{array}$ & $\begin{array}{c}\text { Grade 4 } \\
(\mathrm{n}=98)\end{array}$ \\
\hline The Whole Test (50 items) & .90 & .89 & .87 & .90 \\
Morphological Structure Awareness (40 items) & .87 & .87 & .83 & .88 \\
Affix Identification/ Real Words (10 items) & .83 & .83 & .71 & .88 \\
Compound Words (10 items) & .84 & .89 & .79 & .84 \\
Derivation (10 items) & .64 & .67 & .54 & .68 \\
Affix Identification/ Nonwords (10 items) & .68 & .62 & .71 & .66 \\
Reading Comprehension (10 items) & .79 & .73 & .79 & .80 \\
\hline
\end{tabular}

\section{Means, Standard deviations, Development}

The means and standard deviations are shown in Table 2. In general, the achievements were high, in all cases, the means of the subtest scores were above $50 \%$. Regarding the Morphological Structure Awareness test, the scores were above 70\%. However, there were differences in the different subtests, mean scores ranged between 57 to 95\%. The Affix Identification/Real Words tasks were the easiest for the students; actually, it seemed that this subtest had a ceiling effect in all grades. The most difficult tasks were connected to the Affix Identification/Nonwords subtest in all grades. Standard deviations showed that in general, the tests had good differential power in all grades, except the Affix Identification/Real Words subtest in grade $3(\mathrm{SD}=11.5 \%)$. There is a tendency that standard deviations were higher in grade 2 compared to the other two grade levels. In the case of Reading Comprehension, the scores ranged between 52 and 73\%. The standard deviations were high, indicating that these tasks could differentiate students' reading comprehension skills well. High standard deviations also showed that there were large individual differences especially in the achievements of the Compound Words, the Affix Identification/Nonwords, and the Reading Comprehension subtests.

Table 2. Means and standard deviations in grades 2-4

\begin{tabular}{lcccc}
\hline & Grade 2 Mean & Grade 3 Mean & Grade 4 Mean & Effect of \\
& $(S D)$ & $(S D)$ & $(S D)$ & Grade $(F)$ \\
\hline \multirow{2}{*}{ Morphological Structure Awareness } & 72.09 & 80.35 & 82.47 & $15.50 p<.01$ \\
& $(17.03)$ & $(13.28)$ & $(14.53)$ & \\
Affix Identification/ Real Words & 87.98 & 94.89 & 92.96 & $5.80 p<.01$ \\
& $(20.32)$ & $(11.51)$ & $(17.72)$ & \\
Compound Words & 69.59 & 81.10 & 81.02 & $7.81 p<.01$ \\
& $(31.40)$ & $(22.30)$ & $(23.40)$ & \\
Derivation & 73.08 & 81.32 & 85.30 & $13.46 p<.01$ \\
& $(20.93)$ & $(16.09)$ & $(17.12)$ & \\
Affix Identification/ Nonwords & 56.89 & 64.12 & 70.61 & $9.93 p<.01$ \\
& $(22.23)$ & $(24.17)$ & $(21.58)$ & \\
Reading Comprehension & 52.13 & 68.38 & 73.16 & $19.72 p<.01$ \\
& $(26.51)$ & $(27.11)$ & $(26.19)$ & \\
\hline
\end{tabular}

ANOVA test showed that students' grades had a significant effect on all performances (see Table 2). The post hoc comparisons using Tukey's-b test indicated that all mean scores for grade 2 were significantly different from the mean scores in grade 3 and grade 4 . However, the mean scores in grade 3 did not significantly differ from the results in grade 4 in all tests, except in the Affix Identification/Nonwords subtest. Figure 3 shows the developmental tendencies from grades 2 to 4 . 


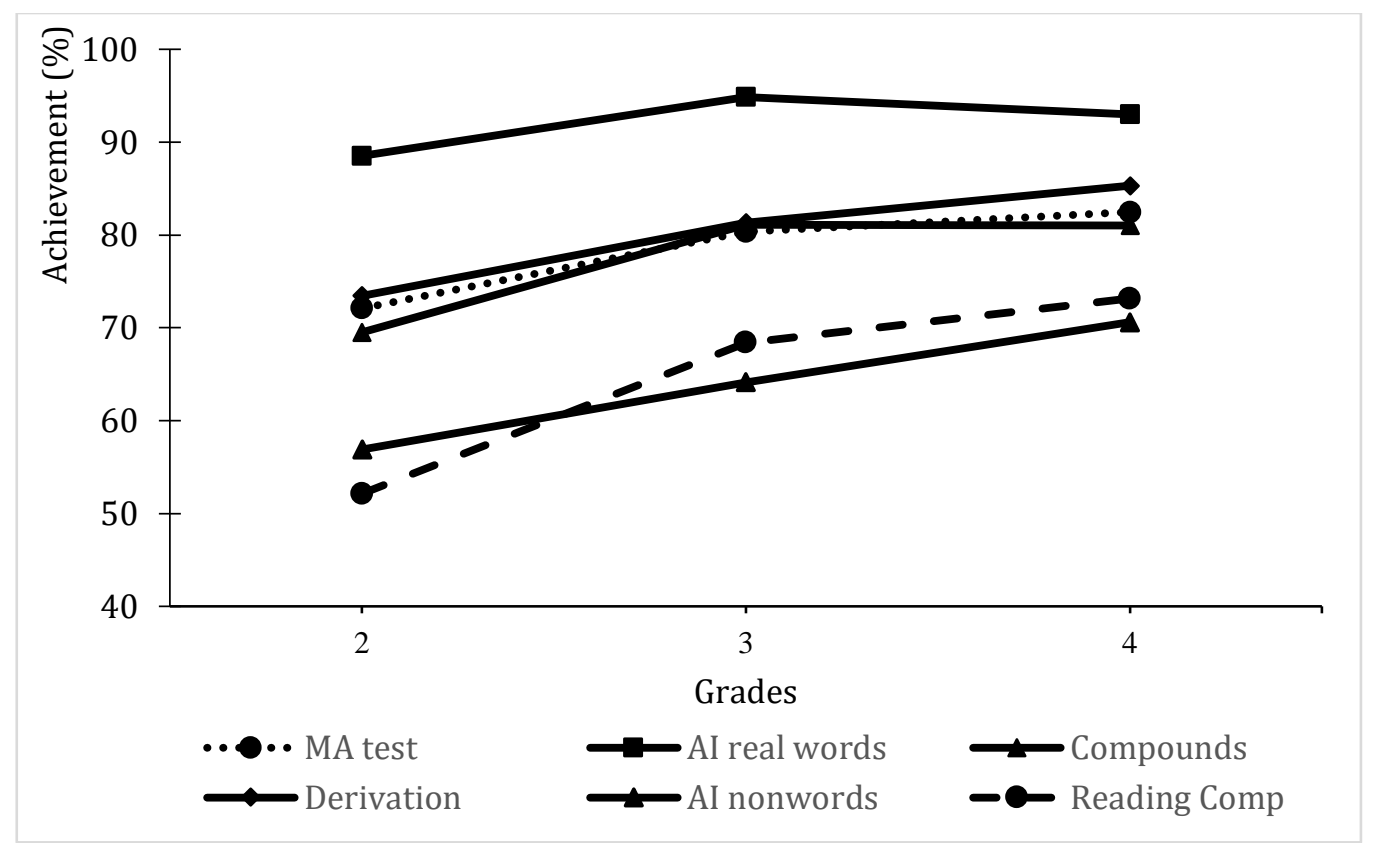

FIGURE 4. The development of the morphological structure awareness in grades 2-4

\section{Relationship between morphological awareness and reading comprehension}

We found significant positive correlations in all grades between the Morphological Structure Awareness and the Reading Comprehension test achievements, the values were similar in magnitude (values range between .56 to .62, see Table 3). Moderate correlations were also found regarding the subtests between the Morphological Structure Awareness test except for the Affix Identification/Real Words subtest where the coefficients were lower, range between .23 to .17. The Affix Identification/Nonwords subtest showed the strongest relationships with Reading Comprehension. The weakest correlations were found between the Affix Identification/Real Words subtest and the reading comprehension scores.

Table 3. Correlations between the subtests in grades 2-4

\begin{tabular}{|c|c|c|c|c|c|}
\hline & $\begin{array}{c}\text { MSAT } \\
\text { Grades: } \\
2-3-4\end{array}$ & $\begin{array}{c}\text { AIRW } \\
\text { Grades: } \\
2-3-4\end{array}$ & $\begin{array}{c}\text { CW } \\
\text { Grades: } \\
2-3-4\end{array}$ & $\begin{array}{c}\text { D } \\
\text { Grades: } \\
2-3-4\end{array}$ & $\begin{array}{c}\text { AINW } \\
\text { Grades: } \\
2-3-4\end{array}$ \\
\hline Affix Identification/Real Words & .59 .46 .67 & & & & \\
\hline Compound Words & .78 .79 .73 & $.20^{*} .30 .25^{*}$ & & & \\
\hline Derivation & .78 .70 .71 & $.33 .17^{*} .39$ & .48 .39 .32 & & \\
\hline Affix Identification /Nonwords & .73 .79 .79 & .36 .14 .40 & .34 .42 .42 & .48 .41 .44 & \\
\hline Reading Comprehension & .56 .60 .62 & $.27 .23 .24^{*}$ & .40 .34 .42 & .37 .39 .51 & .58 .64 .63 \\
\hline
\end{tabular}

Note: Morphological Structure Awareness Test (MSAT), Affix Identification/Real Words (AIRW), Compound Words (CW), Affix Identification/Nonwords (AINW), Derivation (D), Reading Comprehension (RC) Unmarked correlations are significant at the .01 level. Correlations marked with * are significant at the .05 level. Correlation in italics is not significant.

The subtests of the Morphological Structure Awareness test were also correlated with each other, except the Affix Identification/Real Words and the Affix Identification/Nonwords subtests. The coefficient was positive, too, but not significant $(r=14)$. In general, the Affix Identification/Real Words subtest had weaker correlations with all the subtests as well. Nevertheless, the values ranged between .17 to .48 indicating that the constructs behind the subtests were worth measuring separately; they represented important factors of morphological awareness. 


\section{DISCUSSION and CONCLUSIONS}

The purpose of our study was to empirically test an online instrument assessing morphological awareness and reading comprehension in the second, third, and fourth grades of primary school. We also attempted to follow how the two skills develop during the second grade through fourth grade and, to examine the relationship between morphological awareness and reading comprehension skills in the Hungarian language.

\section{Development an online test for assessing morphological awareness and reading comprehension skills}

The overall psychometric properties of the tests were acceptable. The Morphological Structure Awareness and the Reading Comprehension tests had good reliabilities in all grades; however, the Derivation and Affix Identification/Nonwords subtests should be further improved. Standard deviations showed that almost every subtest could differentiate students' abilities especially, among children who had a lower skill level. It is recommended to improve the test with the addition of more difficult tasks on the Affix Identification/Real Words subtest, to address the low standard deviation and high mean scores. These additional items should still allow the test to be administered in a reasonable timeframe. In general, our online test is suitable for the assessment of different aspects of morphological awareness and reading comprehension. Due to the advantages of technology-based assessment the whole measurement, including reading comprehension, could be carried out in a 45-minute lesson. The automatic scoring allowed the children and the teachers to receive immediate feedback on the performances. Teachers could download detailed personalized feedback as well. These properties of the online test make it a suitable assessment tool for everyday teaching practice since it provides teachers knowledge of a child's current level of morphological awareness and reading comprehension skills.

\section{Development of morphological awareness and reading comprehension}

The analysis of the performances of the three age groups showed that there was a significant improvement between grade 2 and grade 3 . An improvement tendency was observed between grades 3 and 4 as well; however, the differences were not statistically significant except in the case of the Affix Identification/Nonwords subtest. Nevertheless, our results suggest that morphological awareness skills are changing parallel with reading comprehension skills in grades 2 to 4 . One reason for the lack of a larger developmental gap between grades 3 and 4 could be the high mean scores, especially in the achievements of the Affix Identification/Real words subtest. The inclusion of more difficult items will help further investigate this phenomenon. An interesting result was that the largest performance differences were between the two subtests assessing affix identification: The mean scores were the lowest with nonwords and highest with real words. The reason for that might be that in exercises using nonwords children cannot rely on the meaning of the words, and therefore; they must rely on their morphological awareness skills.

\section{Relationship between morphological awareness and reading comprehension}

Examination of the correlations in second, third, and fourth grades implies that the participants' performance showed a significant positive correlation between Morphological Structure Awareness and Reading Comprehension tests. The Affix Identification with the Nonwords subtest had the strongest correlation with reading comprehension. This strong relationship gives evidence that these nonword tasks are representing an important factor in children's reading comprehension performances. These exercises expect a more complex cognitive effort from children to understand the rules of forming singular and plural nouns and verbs using suffixes compatible with nouns. Students had to rely only on the structure without knowing the meaning of the word. 


\section{General discussion}

Our results are in line with international research findings (Carlisle, 2000; Kuo \& Anderson, 2006; Levesque et al., 2017) and support that morphological awareness helps learners decompose unknown morphologically complex words into their constituent morphemes and apply morphological rules to derive meanings of unknown words (Apel et al., 2013; Carlisle, 1995; Carlisle, 2000; Casalis et al., 2011; Green \& Volter, 2011; Kinanti et al., 2015). The correlations between students' morphological structure awareness and their reading comprehension suggest that reading comprehension skills are influenced by their morphological structure awareness skills (Apel, et al., 2013; Casalis et al., 2011; Green \& Wolter, 2011). This relationship supports the approach that teaching the structure of the language is essential for effective reading instruction and developing reading skills (Kuo \& Anderson, 2006). Our research results also suggest that morphological awareness seems to work similarly in a language with a shallow orthography and a rich morphological system that is morphological knowledge has an impact on reading skills (Verhoeven \& Perfetti, 2017).

\section{Limitations and directions for further research}

The study has two limitations, the first related to the psychometric properties of the test and the second to small sample size. The low reliabilities and the high mean scores regarding some subtests are already mentioned as the main focus for further research. The future test development could contribute to a more precise and reliable assessment tool as well as the developmental tendencies could be further investigated. In addition, some other dimensions of the constructs could also be included in test development as a means to better understand how awareness of morphological structure influences reading comprehension. For example, phonological awareness or vocabulary subtests might be included. Furthermore, adding more background variables would also be a fruitful endeavor in future research in order to examine other influencing factors of the test achievements.

Although the overall sample size was not small $(\mathrm{N}=359)$, the number of participants in each grade level significantly reduced the generalizability of the findings. Thus, in future research, a larger sample size is an essential step. Applying the advantages of technology-based assessment a large-scale study should be carried out in order to raise the generalizability of the results. The large sample size will allow us to examine the construct validity of our test with confirmatory factor analyses and apply more advanced statistical methods such as structural equation modeling to examine the nature of the constructs and their relationship to each other and other factors as well. Also, a large-scale study will also provide a more reliable and general picture of the development of the measured constructs.

\section{REFERENCES}

Acha, J., Laka, I. \& Perea, M. (2010). Reading development in agglutinative languages: evidence from beginning, intermediate, and adult Basque readers. Journal of Experimental Child Psychology, 1054 , 359-75.

Aro, M. (2017). Learning to Read Finnish. In L. Verhoeven \& C. Perfetti (Eds.), Learning to Read across Languages and Writing Systems (pp. 393-415). Cambridge: Cambridge University Press.

Apel, K., Diehm, E., \& Apel, L. (2013). Using multiple measures of morphological awareness to assess its relation to reading. Topics in Language Disorders, 33(1), 42-56.

Berko, J. (1958). The child's learning of English morphology. Word, 14(2-3), 150-177. Retrieved from http://childes.talkbank.org/topics/wugs/wugs.pdf.

Blomert, L. \& Csépe, V. (2012). Psychological foundations of reading acquisition and assessment. In B. Csapó \& V. Csépe, (Eds.), Framework for diagnostic assessment of reading (pp. 17-78). Budapest: Nemzeti Tankönyvkiadó.

Carlisle, J. F. (1995). Morphological awareness and early reading achievement. In L. B. Feldman (Ed.), Morphological aspects of language processing (pp. 189-209). Hillsdale, NJ: Erlbaum.

Carlisle, J. F. (2000). Awareness of the structure and meaning of morphologically complex words: Impact on reading. Reading and Writing, 12(3), 169-190. 
Casalis, S., Deacon, S. H., \& Pacton, S. (2011). How specific is the connection between morphological awareness and spelling? A study of French children. Applied Psycholinguistics, 32(3), 499-511.

Coltheart, M. (2005). Modeling reading: The dual-route approach. In M. J. Snowling \& C. Hume (Eds.), The science of reading: A handbook (pp. 6-23). Oxford: Blackwell.

Csapó, B. \& Csépe, V. (2012). Introduction. In B. Csapó \& V. Csépe, (Eds.), Framework for diagnostic assessment of reading (pp. 9-16). Budapest: Nemzeti Tankönyvkiadó.

Csapó, B., \& Molnár, G. (2019). Online diagnostic assessment in support of personalized teaching and learning: The eDia System. Frontiers in Psychology, 10, 1522.

Deacon, S. H., Kieffer, M. J., \& Laroche, A. (2014). The relation between morphological awareness and reading comprehension: Evidence from mediation and longitudinal models. Scientific Studies of Reading, 18(6), 432-451.

Deacon, S. H., Tong, X., \& Francis, K. (2017). The relationship of morphological analysis and morphological decoding to reading comprehension. Journal of Research in Reading, 40(1), 1-16.

Gábor, B., \& Lukács, Á. (2012). Early morphological productivity in Hungarian: Evidence from sentence repetition and elicited production. Journal of Child Language, 39(2), 411-442

Gough, P. B., \& Tunmer, W. E. (1986). Decoding, reading, and reading disability. Remedial and special education, 7(1), 6-10.

Grabe, W. \& Stoller F. L (2011). The nature of reading abilities. in Teaching and researching reading.(pp.331) Great Britain: Pearson Education Limited.

Green, L., \& Wolter, J. A. (2011, November). Morphological awareness intervention: Techniques for promoting language and literacy Success. Paper presented the annual American Speech Language Hearing Association, San Diego, CA.

Katz, L. \& Frost, R. (1992). The reading process is different for different orthographies: The orthographic depth hypothesis. In Frost, R. \& Katz, L., (Eds.). Orthography, Phonology, Morphology, and Meaning (pp. 67-84). Amsterdam: Elsevier North Holland Press.

Kinanti, K., Setiyadi, A. B., \& Suparman, U. (2015). The relationship between students' morphological awareness and their reading comprehension. U-JET, 4(4),1-12. Retrieved from http://jurnal.fkip.unila.ac.id/index.php/123/article/view/9184

Kirby, J. R., Deacon, S. H., Bowers, P. N., Izenberg, L., Wade-Woolley, L., \& Parrila, R. (2012). Children's morphological awareness and reading ability. Reading and Writing, 25(2), 389-410.

Kuo, L. J., \& Anderson, R. C. (2006). Morphological awareness and learning to read: A cross language perspective. Educational Psychologist, 41(3), 161-180.

Levesque, K. C., Kieffer, M. J., \& Deacon, S. H. (2017). Morphological awareness and reading comprehension: Examining mediating factors. Journal of experimental child psychology, 160, 1-20.

MacWhinney, B. (1976). Hungarian research on the acquisition of morphology and syntax. Journal of Child Language, 3(3), 397-410.

Nagy, W. E., Carlisle, J. F., \& Goodwin, A. P. (2014). Morphological knowledge and literacy Acquisition. Journal of Learning Disabilities, 47(1), 3-12.

Nunes, T., Bryant, P., \& Bindman, M. (1997). Morphological spelling strategies: Developmental stages and processes. Developmental Psychology, 33(4), 637-649.

Pléh, Cs. (2000). A magyar morfológia pszicholingvisztikai aspektusai [Psycholinguistic aspects of Hungarian morphology]. In F. Kiefer (Ed.), Strukturális magyar nyelvtan. 3. kötet. Morfológia (pp. 951-1020). Budpest: Akadémiai Kiadó.

Rastle, K. (2019). The place of morphology in learning to read in English. Cortex, 116, 45-54.

Verhoeven, U. \& Perfetti C. A. (2011). Introduction to this special issue: Vocabulary growth and reading skill. Scientific Studies of Reading, 15(1), 1-7.

Verhoeven, L., \& Perfetti, C. (2017). Introduction: Operating principals in learning to read. In L. Verhoeven \& C. Perfetti (Eds.), Learning to Read across Languages and Writing Systems (pp. 1-31). Cambridge: Cambridge University Press.

Vygotsky, L., S. (1962). Thought and language. Cambridge, MA: MIT Press.

Ziegler, J. C., \& Goswami, U. (2005). Reading acquisition, developmental dyslexia, and skilled reading across languages: A psycholinguistic grain size theory. Psychological Bulletin, 131(1), 3-29. 